\title{
Antibacterial activity of Miswak (Salvadora persica) extracts against isolated and genetically identified oral cavity pathogens
}

\author{
Abd El-Latif Hesham ${ }^{\mathrm{a}, \mathrm{b}, *}$ and Sulaiman A. Alrumman ${ }^{\mathrm{a}}$ \\ ${ }^{a}$ Biology Department, Faculty of Science, King Khalid University, Abha, Saudi Arabia \\ ${ }^{\mathrm{b}}$ Genetics Department, Faculty of Agriculture, Assiut University, Assiut, Egypt
}

\begin{abstract}
.
BACKGROUND: Despite medical progress worldwide, dental caries are still widespread. Miswak is derived from the plant Arak (Salvadora persica). It is used by Muslim peoples as a natural product for the cleansing of teeth, to ensure oral and dental hygiene.

OBJECTIVE: This study was conducted to evaluate the antimicrobial effects of ethanol, methanol, and ethanol/methanol extracts of Miswak against three bacterial pathogens of the oral cavity.

METHODS: The pathogens were isolated from the oral cavity of volunteers/patients and were identified on the basis of $16 \mathrm{~S}$ rRNA gene amplification data. Sequence comparisons were made with 16S rRNA gene sequences available in the GenBank database.

RESULTS: The results of sequence alignment and phylogenetic analysis identified the three pathogens as being Staphylococcus aureus strain KKU-020, Enterococcus faecalis strain KKU-021 and Klebsiella pneumoniae strain KKU-022. All Miswak extracts showed powerful antimicrobial activity against the three pathogens. The maximum zone of inhibition $(40.67 \pm 0.88 \mathrm{~mm})$ was observed against $E$. faecalis KKU-021 with ethanolic extracts whilst methanolic extracts showed the minimum zone of inhibition (10.33 $\pm 0.88 \mathrm{~mm}$ ) against $K$. pneumonia $\mathrm{KKU}-022$.

CONCLUSION: Based upon the significant effects of the Miswak extracts, against the oral cavity pathogens in our study, we recommend that Miswak could be used as a dental hygiene method to prevent tooth caries.
\end{abstract}

Keywords: Salvadora persica, Miswak, antibacterial activities, oral cavity pathogens, 16S rRNA gene sequences, phylogenetic analysis

\section{Introduction}

Tooth caries are one of the most widespread, chronic problems in public health worldwide. This oral disease, affects $60-90 \%$ of school children [1]. Miswak is derived from the plant Arak (Salvadora persica) which belongs to the Salvadoraceae family, and is an Arabic word meaning tooth-cleaning stick. The spread of Islamic culture played a role in the spread of cultivation and the use of Miswaks for tooth-cleaning, in different parts of the world [2]. The Miswak chewing stick is mentioned in Ahadith (TALKS) by the prophet Mohamed "Peace be upon him"; it is used by the majority of Muslims worldwide [3]. As Miswak wicks are flexible, strong and do not damage the gums, they can be made into the appropriate shape to clear plaque and remove food from between teeth [4].

\footnotetext{
${ }^{*}$ Corresponding author: Abd El-Latif Hesham, Biology Department, Faculty of Science, King Khalid University, Abha, Saudi Arabia. E-mail: hesham_egypt5@aun.edu.eg; hesham_egypt5@agr.au.edu.eg.
}

0928-7329/16/\$35.00 (C) 2016 - IOS Press and the authors. All rights reserved This article is published online with Open Access and distributed under the terms of the Creative Commons Attribution NonCommercial License. 


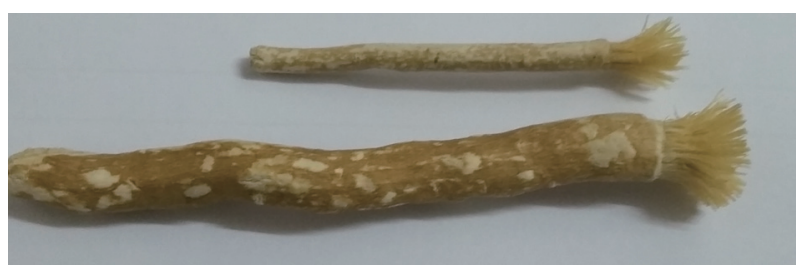

Fig. 1. Miswak which is mainly obtained from slim branches of Arak plant.

Miswak (Fig. 1) is mainly obtained from slim branches of Arak and to a lesser degree from the woody roots of the tree [5]. Recently, it has been reported by some researchers that extracts of Miswak posses various pharmaceutical properties against microorganisms, including bacteria [6,7], and fungi $[6,8,9]$.

The World Health Organization (WHO), which is a specialized agency of the United Nations (UN) that is concerned with international public health, recommended the use of Miswak for cleansing teeth in 1986 and in 2000. There was a report concerning the international consensus on oral hygiene which recommended that further research was needed to assess the effect of Miswak [4].

These factors make research into the effects of Miswak an area of great interest. Therefore, our study was aimed toward the evaluation of the antimicrobial effects of ethanol, methanol, and ethanol/methanol extracts of $S$. persica Miswak against three isolated oral bacterial pathogens. 16S rRNA gene amplification, sequence alignment and phylogenetic analysis were utilized to identify pathogens at the species level.

\section{Materials and method}

\subsection{The isolation of pathogenic bacteria from the oral cavity}

Saliva and swabs of plaque were collected from patients with dental caries and stored at $4{ }^{\circ} \mathrm{C}$ in the laboratory until to use. Pathogens were isolated on nutrient agar plates and characterized according to the tests of positive and negative gram staining.

\subsection{PCR amplification of $16 \mathrm{~S}$ rRNA gene and sequence determination}

The Genomic DNA was extracted from the isolated bacteria according to the method previously described by Hesham et al. [10] and the 16S rRNA gene was amplified. Amplification was carried out with universal primers: 27F (5-AGAGTTTGATCCTGGCTCAG-3) and 1492R (5CGGCTACCTTGTTACGACTT-3) [11]. The PCR reaction was performed in a final volume of $50 \mu 1$ containing GoTaq green master mix (Promega, Madison, WI, USA), $1 \mu 1$ of each primer at a concentration of $0.5 \mathrm{mM}$, and $1 \mu \mathrm{l}$ template DNA. PCR was performed with the following program: 5 min denaturation at $95^{\circ} \mathrm{C}$, followed by 36 cycles of 1 min denaturation at $94^{\circ} \mathrm{C}, 1$ min annealing at $55^{\circ} \mathrm{C}$, $1.5 \mathrm{~min}$ extension at $72^{\circ} \mathrm{C}$ and a final extension step of $7 \mathrm{~min}$ at $72^{\circ} \mathrm{C}$. Five $\mu \mathrm{l}$ of the amplified mixture was then analyzed using $1.5 \% 0.5 \times$ TBE agarose gel electrophoresis. The gel was stained with ethidium bromide, visualized under UV light, and photographed. The product of the correct size (1500 bp) was purified and sequenced in both directions using an $\mathrm{ABI}$ automated sequencer (Macrogen Company, Korea). 


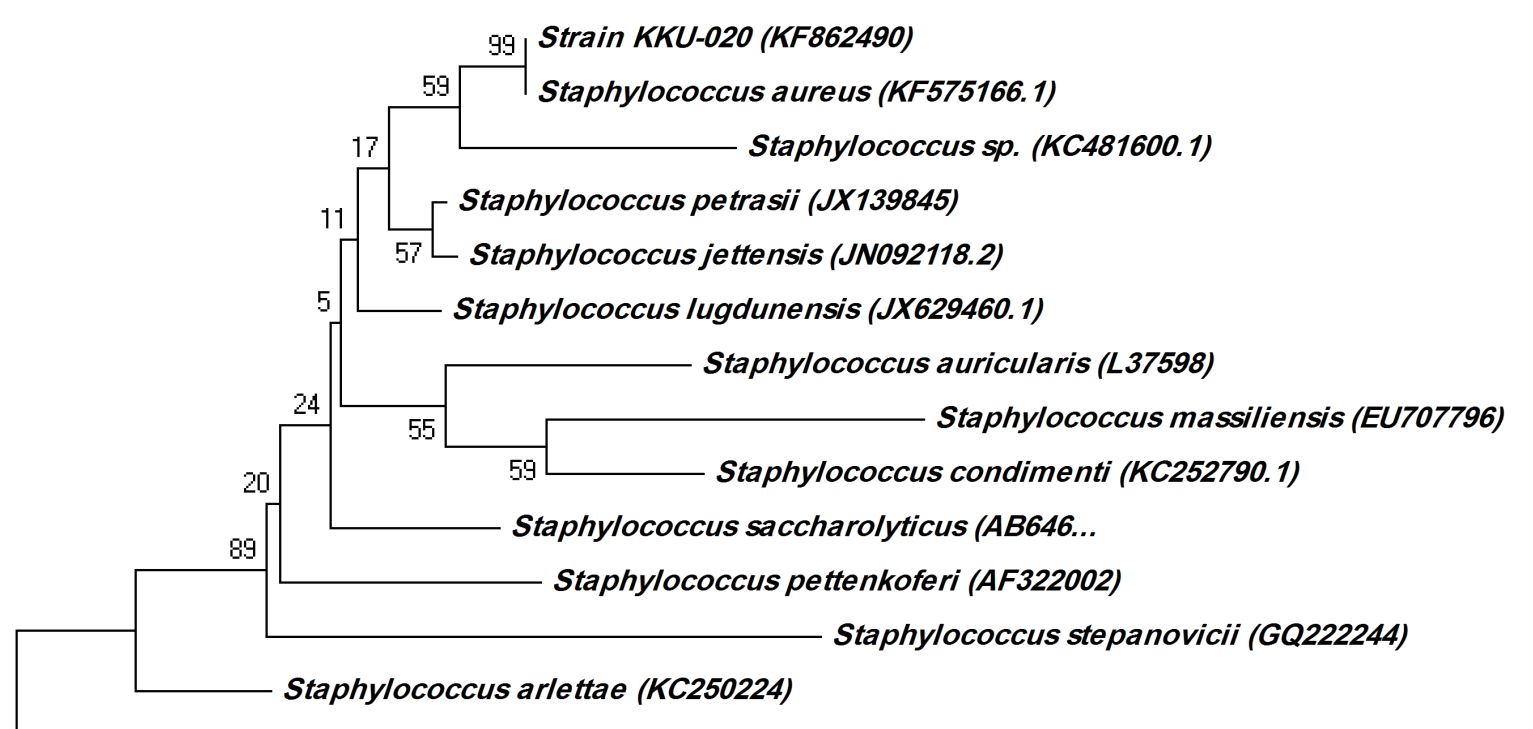

Staphylococcus cohnii (KC707548.1)

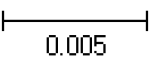

Fig. 2. Phylogenetic analysis of 16S rRNA gene of strain KKU-020 and other related Staphylococcus spp. by the Neighbor-Joining method. Numbers at the nodes indicate bootstrap support (\%) based upon 100 replicates. The scale bar indicates 0.005 nucleotide substitutions per nucleotide position. GenBank accession numbers are given in parentheses.

\subsection{Sequence alignment and phylogenetic analysis}

The 16S rRNA gene sequences of the isolates obtained in this study were aligned and compared with known 16S rRNA gene sequences in the GenBank database. This was done using the BLAST search made available by the National Center for Biotechnology Information (http://www.ncbi.nlm.nih.gov/ BLAST/) to determine the closest available database sequences. To determine the taxonomic position of the isolates, phylogenetic trees were constructed with MEGA version 4.0. This used a neighborjoining algorithm, plus the Jukes-Cantor distance estimation method with bootstrap analyses for 1,000 replicates [12].

\subsection{Plant material collection}

Stems of S. persica Miswak were purchased from local markets in Abha city, Saudi Arabia. Miswak samples were shade dried and then powdered using a suitable grinder.

\subsection{Preparation of S. persica Miswak extracts}

A fine powder was extracted in different three solvents including ethanol, methanol and ethanol/ methanol (v/v), using a soxhlet extractor as described by Chhabra et al. [13]. Dried extracts were weighed, dissolved in sterile dimethyl sulfoxide (DMSO) and utilized for the antibacterial activity test. 


\subsection{In vitro antibacterial assay}

In vitro antibacterial activities of the Miswak extracts were determined by an agar well diffusion assay according to the procedure described by Ettebong and Nwafor [14]. The experiment was performed in triplicate, two controls were used, streptomycin (30 $\mu \mathrm{g} / \mathrm{disc})$ as positive control and DMSO as negative control. Plates were incubated at $37^{\circ} \mathrm{C}$ overnight. The antibacterial activity of each extract was determined by measuring the diameter of the zone of inhibition in millimeters (mm). Analysis of variance (ANOVA) was carried out to detect the significance of differences among the treatment means.

\subsection{GenBank nucleotide accession numbers}

The nucleotide sequences of the 16S rRNA gene of the isolated strains KKU-020, KKU-021 and KKU-022 reported in this study have been deposited in the DDBJ, EMBL, and GenBank nucleotide sequence databases under Accession Numbers: KF862490, KF862491 and KF862492, respectively.

\section{Results}

\subsection{Oral pathogen isolation and staining characterization}

The three pathogens isolated were designated as KKU-020, KKU-021 and KKU-022 and were selected and characterized by positive and negative gram staining. The results confirmed that the pathogens KKU-020 and KKU-021 were gram positive whilst KKU-022, was gram negative.

\subsection{Genetic identification and phylogenetic analysis using $16 S$ rRNA gene sequences}

For genetic identification, the total genomic DNA of each pathogen (KKU-020, KKU-021 and KKU022) was extracted and a pair of universal primers $27 \mathrm{~F}$ and $1492 \mathrm{R}$ were used for $16 \mathrm{~S}$ rRNA gene amplification and sequencing. The 16S rRNA gene sequences of the isolated pathogens KKU-020, KKU-021 and KKU-022 were aligned and compared with the $16 \mathrm{~S}$ rRNA gene sequences published in the GenBank database by a BLAST search. Results showed that the sequences of the isolated pathogens KKU-020, KKU-021 and KKU-022 were highly similar (100\% similarity) to Staphylococcus aureus, Enterococcus faecalis, and Klebsiella pneumonia, respectively. To assert the taxonomic location of each strain in phylogeny, a number of sequences representative of some Staphylococcus, Enterococcus and Klebsiella species were selected from the GenBank database for phylogenetic tree construction. Results in Fig. 2 showed that isolated KKU-020 and S. aureus occupied one cluster. Therefore, the KKU-020 was identified as $S$. aureus. However, the results displayed in Fig. 3 revealed that the isolate KKU-021 and $E$. faecalis were in the same clade cluster. Therefore, the isolate KKU-021 was identified as E. faecalis. The third pathogen KKU-022 was confirmed as K. pneumoniae whereas KKU-022 and K. pneumoniae were found in one cluster (Fig. 4). 


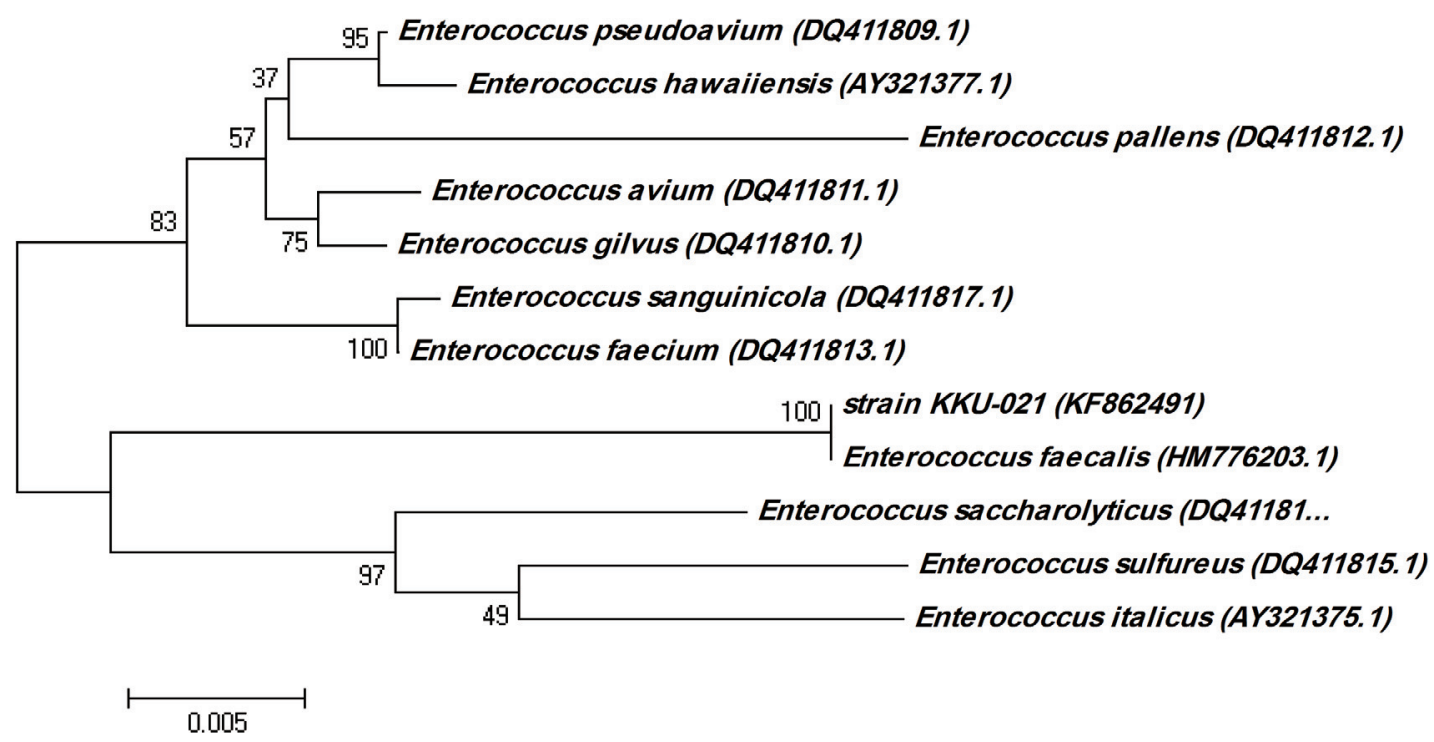

Fig. 3. Phylogenetic analysis of $16 \mathrm{~S}$ rRNA gene of strain KKU-021 and other related Enterococcus spp. by Neighbor-Joining method. Numbers at the nodes indicate bootstrap support (\%) based upon 100 replicates. The scale bar indicates 0.005 nucleotide substitutions per nucleotide position. GenBank accession numbers are given in parentheses.

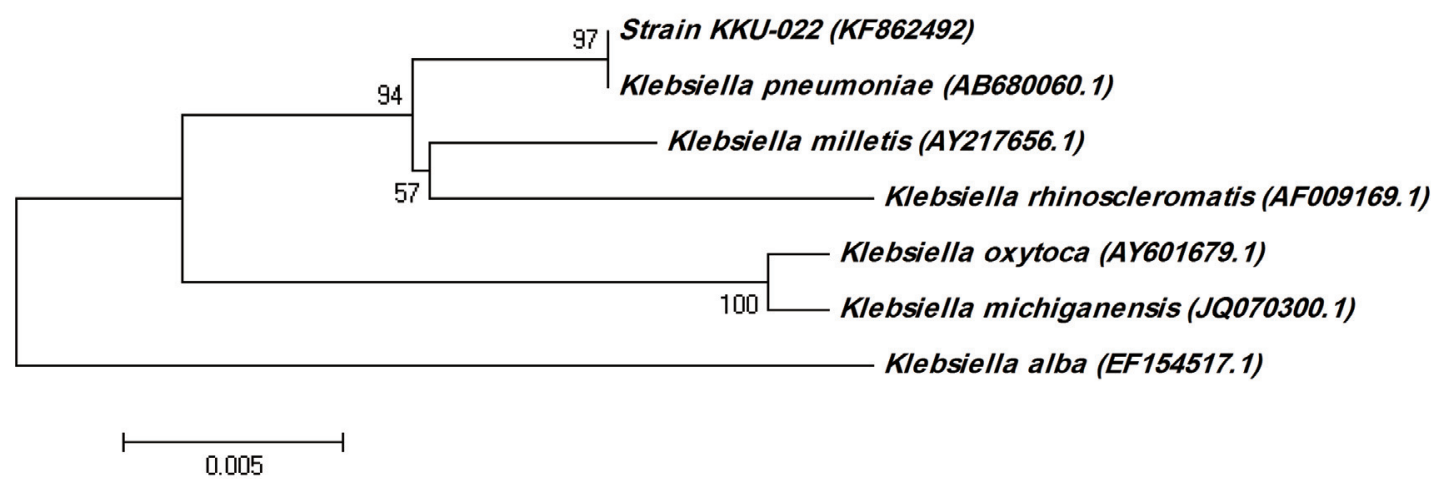

Fig. 4. Phylogenetic analysis of 16S rRNA gene of strain KKU-022 and other related Klebsiella spp. by Neighbor-Joining method. Numbers at the nodes indicate bootstrap support (\%) based upon 100 replicates. The scale bar indicates 0.005 nucleotide substitutions per nucleotide position. GenBank accession numbers are given in parentheses.

\subsection{The antibacterial activity of Miswak extracts}

The antimicrobial effects of ethanol, methanol and ethanol/methanol extracts of $S$. persica Miswak against three isolated oral pathogens, (KKU-020 and KKU-021 gram positive and KKU-022 gram negative), are displayed below. Results in Table 1 showed that all the extracts were active against all tested oral pathogens with an inhibition zone which ranged between $10.33 \pm 0.88 \mathrm{~mm}$ to $40.67 \pm 0.88 \mathrm{~mm}$. The highest activity was noted against $E$. faecalis KKU-021 followed by $S$. aureus KKU-020 and then $K$. pneumoniae KKU-022. The maximum zone of inhibition $(40.67 \pm 0.88 \mathrm{~mm})$ was achieved against E. faecalis KKU-021 by the ethanolic extract. The methanolic extract showed the minimum zone of inhibition (10.33 $\pm 0.88 \mathrm{~mm}$ ) against $K$. pneumonia KKU-022 (Table 1). 
Table 1

Zone of inhibition $(\mathrm{mm}) \pm$ standard error. Different superscript letters show significant differences (One way ANOVA, Tukey test, $P \leqslant 0.05$ )

\begin{tabular}{lccc}
\hline & \multicolumn{3}{c}{ Extraction methods } \\
\cline { 2 - 4 } Microorganisms & Ethanol & Methanol & Ethanol+ methanol \\
\hline Staphylococcus aureus & $19.33^{\mathrm{a}} \pm 0.88$ & $17.00^{\mathrm{a}} \pm 0.58$ & $21.00^{\mathrm{a}} \pm 0.58$ \\
Enterococcus faecalis & $40.67^{\mathrm{b}} \pm 0.88$ & $27.33^{\mathrm{b}} \pm 0.88$ & $31.33^{\mathrm{b}} \pm 0.88$ \\
Klebsiella pneumoniae & $12.67^{\mathrm{c}} \pm 0.67$ & $10.33^{\mathrm{c}} \pm 0.88$ & $16.00^{\mathrm{c}} \pm 0.58$ \\
\hline
\end{tabular}

\section{Discussion}

This study aimed to evaluate different extracts of Miswak against oral pathogenic bacteria. Pathogens were isolated from saliva and carie lesion samples, collected from patients with dental caries. Molecular methods based upon 16S rRNA gene sequences and phylogenetic analysis were used to identify isolated pathogens at the species level. Molecular results confirmed that the pathogen KKU-020 was $S$. aureus (Fig. 2), KKU-021 was E. faecalis (Fig. 3) and KKU-022 was K. pneumoniae (Fig. 4). Molecular genetic identification techniques based upon the sequence analysis of the 16S rRNA gene have become the golden index and are powerful tools for bacterial identification $[12,15,16]$. Nowadays, 16S rRNA gene amplification by PCR and sequencing using automated sequencer provides a valuable and reliable way for the identification of pathogenic bacteria [17].

Maintaining a healthy mouth and dental hygiene leads to a better quality of life. Many human diseases can arise due to lack of oral hygiene and tooth caries. The vast majority of Muslims worldwide use Miswak chewing stick for the purposes of cleaning teeth. Oral health is a sunnah (PRACTICES OF THE PROPHET) from Mohamed the Prophet of Allah "Peace be upon him" where he "Peace be upon him" recommended it be used before every prayer. The Hadith, TALK, mentioned the importance of using Miswak. The prophet Mohamed "peace be upon him" said: 'Was it not for my fear of imposing a difficulty on my Ummah, (A NATION) I would have ordered that the Miswak be used for every Salaat (PRAYER) (Al-Bukhari)'.

Recently, it has been reported that Miswak prevents many diseases of the oral cavity, gastro-intestinal tract and heart [18]. Therefore, the WHO recommended the use of Miswak for the cleansing of teeth and that further research was needed into the effect of Miswak [4].

Considering this new knowledge, concerning the activity of ethanol, methanol, and ethanol/methanol $(\mathrm{v} / \mathrm{v})$ extracts of $S$. persica Miswak, tested for their inhibitory effects on the growth of isolated oral bacterial pathogens (S. aureus KKU-020, E. faecalis KKU-021 and K. pneumoniae KKU-022). Results showed that all the extracts were active against the oral pathogens. The highest effective activity was noted against $E$. faecalis KKU-021 followed by $S$. aureus KKU-020, whilst the lowest activity was observed against $K$. pneumonia KKU-022. Sofrata et al. [19] reported S. persica Miswak had acute effects against oral microorganisms. In addition, in an investigation which used extracts of $S$. persica against microorganisms, Almas et al. [20] found that E. faecalis was the most sensitive pathogen. This study also reported that there was no significant difference in the effects of fresh and old cuttings of Miswak.

The results in Table 1 showed that maximum zone of inhibition $(40.67 \pm 0.88 \mathrm{~mm})$ against E. faecalis KKU-021 was gained by the ethanolic extract. The methanolic extract showed a minimum zone of inhibition $(10.33 \pm 0.88 \mathrm{~mm})$ against $K$. pneumonia KKU-022 indicating ethanolic extract more effective than methanolic extract. A comparative study investigated the effect of ethanolic and aqueous extracts of S. persica Miswak against oral pathogens; found that the ethanolic extract had strong antimicrobial 
activity than aqueous extract [21]. Another study showed that the aqueous extract was more effective than the methanolic extract against isolated oral microorganisms [4].

Our results confirmed the beneficial effect of S. persica Miswak on oral health that may due to the presence of important compounds, which have anticariogenic effect. Benzylisothiocyanate, salvadorine and fluoride were found to prevent cariogenic and inhibit the growth of bacteria [22-24]. Tannins were found to reduce gingivitis [25,26], vitamin C help in tissue healing [23], and silica and chloride removing stains and helpful in tooth whitening [6,27]. The essential oils in S. persica Miswak that has bitter taste stimulate the flow of saliva, which promote enamel remineralization [26,28].

When the beneficial effect of $S$. persica Miswak was compared with synthetic toothbrushes, Miswak was found to be more effective than the synthetic one for oral hygiene and treat gum inflammation [25, 29-31].

\section{Conclusion}

In conclusion, our study was aimed toward the evaluation of the antimicrobial effects of S. persica Miswak extracts against three isolated oral bacterial pathogens. 16S rRNA gene amplification, sequence alignment and phylogenetic analysis were utilized to identify pathogens at the species level. the present study confirms that Miswak has a significant antimicrobial effect upon oral pathogens including both Gram-positive and Gram-negative microbes. Based on this scientific knowledge Miswak can be recommended as an excellent oral and dental hygiene agent, to prevent tooth caries.

\section{References}

[1] Patro Binod K., Ravi Kumar B., Goswami A., Prakash Mathur V., Nongkynrih B. Prevalence of dental caries among adults and elderly in an urban resettlement colony of New Delhi. Indian Journal of Dental Research. 2008; 19: 95-98.

[2] Bos G. The miswak, an aspect of dental care in Islam. Medical History. 1993; 37: 68-79.

[3] Goyal M., Sasmal D., Nagori B. Salvadora persica (Meswak): chewing stleck for complete oral care. International Journal of Pharmacology. 2011; 7(4): 440-445.

[4] Al-Bayati AF., Sulaiman KD. In Vitro Antimicrobial Activity of Salvadora persica L. Extracts Against Some Isolated Oral Pathogens in Iraq. Turkish Journal of Biology. 2008; 32: 57-62.

[5] Araya YN. Contribution of Trees for Oral Hygiene in East Africa. Ethnobotanical Leaflets. 2007; 11: 38-44.

[6] Chelli-Chentouf N., Meddah ATT., Mullie C., Aoues A., Meddah B. In vitro and in vivo antimicrobial activity of Algerian Hoggar Salvadora persica L. extracts against microbial strains from children's oral cavity. Journal of Ethnopharmacology. 2012; 144: 57-66.

[7] Sher H., AlYamani MN., Wijaya L. Ethnobotanical and antibacterial potential of Salvadora persica: a well known medicinal plant in Arab and union system of medicine. Journal of Medicinal Plants Research. 2011; 5: 1224-1229.

[8] Al-Bagieh NH., Idowu A., Salako NO. Effect of aqueous extract of miswak on the in vitro growth of Candida albicans. Microbios Letters. 1994; 80: 107-113.

[9] Noumi E., Snoussi M., Hajlaoui H., Valentin E., Bakhrouf A. Antifungal properties of Salvadora persica and Juglans regia L. extracts against oral Candida strains. European Journal of Clinical Microbiology \& Infectious Diseases. 2010; 29: 81-88.

[10] Hesham A., Wang Z., Zhang Y., Zhang J., Lv W., Yang M. and identification of a yeast strain capable of degrading fourand five ring aromatic hydrocarbons, Annals of Microbiology. 2006; 56: 109-112.

[11] Lane DJ. 16S/23S rRNA sequencing. In: Stackebrandt E, Goodfellow M (eds) Nucleic acid techniques in bacterial systematic.. Wiley, New York. 1991. pp 115-175.

[12] Hesham A., Mohammed NH., Ismail MA, Shoreit AA. 16S rRNA gene sequences analysis of Ficus elastica rubber latex degrading thermophilic Bacillus strain ASU7 isolated from Egypt. Biodegradation. 2012; 23: 717-724.

[13] Chhabra SC., Shao TF., Mshiu EN. Antifungal activity among traditionally used herbs in Tanzania. The Dar Medical Journal. 1982; 9: 68-73. 
[14] Ettebong E., Nwafor P. In vitro antimicrobial activities of extracts of Carpolobia lutea root. Pakistan Journal of Pharmaceutical Sciences. 2009; 22(3): 335-338.

[15] Rani MS., Lakshmi KV., Devi PS. Isolation and characterization of a chlorpyrifos degrading bacterium from agricultural soil and its growth response. African Journal of Microbiological Research. 2008; 2: 26-31.

[16] Wu XY., Walker MJ., Hornitzky M., Chin J. Development of a group-specific PCR combined with ARDRA for the identification of Bacillus species of environmental significance. Journal of Microbiological Methods. 2006; 64: 107119.

[17] Jenkins C., Ling LL., Ciesielczuk HL., Lockwood J., Hopkins S., McHugh TD., et al. Detection and identification of bacteria in clinical samples by $16 \mathrm{~S}$ rRNA gene sequencing: comparison of two different approaches in clinical practice. Journal of Medical Microbiology. 2012; 61(4): 483-488.

[18] Khan AS., Khan MA., Din HA., Khan HU., Tayyab M. Some Scientific Facets of Quran and Sunnah (of the Prophet Muhammad, Peace Be Upon Him) in The Field of Medicine. Pakistan Journal of Health. 1994; 31: 7-10.

[19] Sofrata A., Claesson R., Lingstrom P., Gustafsson A. Strong antibacterial effect of miswak against oral microorganisms associated with periodontitis and caries. Journal of Periodontology. 2008; 79(8): 1474-1479.

[20] Almas K., Al-Bagieh N., Akpata E. In vitro antimicrobial effects of freshly cut and 1-month old miswak (chewing stick). Biomedical Letters. 1997; 56: 145-149.

[21] Al-Bagieh N., Almas K. In vitro antibacterial effects of aqueous and alcohol extracts of miswak (chewing sticks). Cairo Dental Journal. 1997; 13: 221-224.

[22] Al-Bagieh N., Weinberg E. Benzolisothiocyanate: a possible agent for controlling dental caries. Microbios Letters. 1998; 39: $143-151$.

[23] Almas K. Miswak (chewing stick) and its role in oral health. Postgraduate Dental. 1993; 3: 214-218.

[24] Hattab F. Meswak: the natural toothbrush. Journal Clinical Dental. 1997; 8(5): 125-129.

[25] Al-Otaibi M., Al-Harthy M., Soder B., Gustafsson A., Angmar-Mansson B. Comparative effect of chewing sticks and tooth brushing on plaque removal and gingival health. Oral Health \& Preventive Dentistry. 2003; 1: 301-307.

[26] Gazi M., Davies T., Al-Bagieh N., Cox S. The immediate- and medium-term effects of Meswak on the composition of mixed saliva. Journal of Clinical Periodontology. 1992; 19(2): 113-117.

[27] Al Lafi T., Ababneh H. The effect of the extract of the miswak (chewing sticks) used in Jordan and the Middle East on oral bacteria. International Dental Journal. 1995; 45: 218-222.

[28] Kaur S. The Effect of Chewing Miswak (Salvadora persica) on Flow Rate, pH, and Levels of Calcium Phosphate, Chloride and Thiocyanatein Mixed Saliva, Dissertation of Master of Dental Science (MDSc), Faculty of Dentistry, University of Malaya, 2011.

[29] Almas K., Al-Zeid Z. The immediate antimicrobial effect of a toothbrush and miswak on cariogenic bacteria: a clinical study. The Journal of Contemporary Dental Practice. 2004; 5: 105-114.

[30] Bhat PK., Amit Kumar A., Soumik Sarkar S. Assessment of immediate antimicrobial effect of miswak extract and toothbrush on cariogenic bacteria - A clinical study. Journal of Advanced Oral Research. 2012; 3(1): 13-18.

[31] Dina M., Alhelawe S. Influence of miswak on the Binding of Polyphenols to Protein Pellicle, Memorial High School, Ocean Twp, NJ Parts of Medicinal Chemistry Posters, 2005. 